\title{
South Korea's Development Success: Lessons for Uganda
}

\author{
Denis Musinguzi ${ }^{1}$
}

(C) Uganda Martyrs University

\begin{abstract}
From a least developed and aid receiving country to a developed and donor country within six decades, South Korea represents one of the unprecedented world's phenomenal and remarkable development experience. A combination of political and economic elements has been the key driver behind Korea's development success. Traditional and contemporary factors worked symbiotically to accelerate Korea's miraculous economic development and rapid socio-economic transformation. Traditional factors include prodigious savings, focus on exports, investment in human and infrastructure capital, strong macroeconomic policies, and a capable government with a long-term development vision. Contemporary factors include effective economic planning, strong business-government links, investment in research and development, adaptable economic policies and an emphasis on tertiary education. Through effective usage of aid that it benefitted from, Korea now extends the same generosity to developing countries, including Uganda. The article explores this unprecedented and 'miraculous' experience, and draws lessons for Uganda and other developing countries.
\end{abstract}

Key terms $\cdot$ Development $\cdot$ economic growth $\cdot$ foreign aid $\cdot$ poverty reduction

Ce que l'Ouganda peut apprendre du succès de développement de la Corée du Sud

Résumé. D'un des pays les moins développés et receveur d'aide étrangère à un pays développé et un pays donateur d'aide dans les six dernières décennies, la Corée du Sud constitue une exprerience planétaire de développement phenomenale et sans précédent. Une combinaison d'éléments économiques et politiques a été le principal instigateur derrière le succès de développement de la Corée du Sud. Les facteurs traditionnels et contemporains ont travaillé en symbiose pour accélérer le développement économique de la Corée du Sud ainsi que sa miraculeuse et rapide transformation socio-économique. Les facteurs traditionnels : épargne prodigieuse, l'accent sur les exportations, l'investissement en capital et dans l'infrastructure, des politiques macroéconomiques fermes, et un gouvernement capable d'une vision de développement à long terme. Facteurs contemporains: la planification économique efficace, liens solides entre le gouvernement et le secteur privé, des investissements en recherche pour le développement, d'adaptation des politiques économiques et l'accent sur l'enseignement supérieur. Grâce à l'utilisation efficace de l'aide dont elle a été précédemment bénéficiaire, la Corée du Sud tend maintenant la même générosité à l'égard des pays en voie développement, y compris l'Ouganda. L'article explore cette experience 'miraculeuse et sans précédent' et en tire des leçons pour l'Ouganda et d'autres pays en voie de développement.

Termes clés: Le développement • la croissance économique $\bullet$ l'aide étrangère $・$ la réduction de la pauvreté

\section{Introduction}

According to the Korean International Cooperation Agency (KOICA), South Korea underwent miraculous development experience and rapid transformation from a least developed and aid receiving country to a developed and donor country within six decades (KOICA, 2011), which this article explores. The aim is to learn from this inspiring development experience with the view of ascertaining benchmarks for analysing growth issues and prospects in developing countries and also draw lessons

\footnotetext{
${ }^{1}$ Uganda Martyrs University, Email: dmusinguzi@umu.ac.ug
} 
that would inform development planning, policy and strategies for developing countries, with particular focus on Uganda. The article highlights Korea's development initiatives in Uganda and shows, with particular credit, how its model has responded to national development objectives and priorities through responsive, community-based, demand-driven and participatory models conducive to Uganda's equitable and sustainable growth and development. Specifically, South Korea's impressive growth and development experience is presented as a viable model for equitable and sustainable development in Uganda and other developing countries in general.

Founded on April 1, 1991, KOICA is Korea's international official development aid coordination and supervision agency, operating within Asia and the Pacific, Eastern Europe and the Common Wealth of Independent States, Africa, Central and South America, and the Middle East. According to KOICA's Mission, "Happiness for $A l l$ ", Korea's and indeed global development cooperation efforts were in the past focused mainly on meeting the Basic Human Needs (BHNs) of developing countries and fostering their Human Resources Development (HRD). However, the focus has overtime broadened to promote sustainable development, strengthen partnerships, and enhance the local ownership of the supported development projects by the beneficiaries. In addition, global concerns such as the environment, poverty reduction, and gender mainstreaming, have gained significant importance in the international community. KOICA's performance sectors include Education, Health, Governance, Information Communication Technology (ICT), Rural Development, Industry and Energy, and Environment among others. KOICA's cardinal role is to maximise the effectiveness of Korea's grant aid programmes for developing countries by implementing the government's grant aid and technical cooperation programmes (KOICA, 2011).

\section{A note on methodology}

Informed by critical theory research paradigm, this was an empirical study that sought to document South Korea's development experience, both broadly and with specific reflection on KOICA's activities in Uganda. Drawing from its key assumptions that international politics reflect constructions of powerful state actors and statesmen; and that structures of world politics and economy are oppressive of underprivileged nations and people, critical theory stands for emancipatory knowledge that seeks to empower the subalterns. Given South Korea's rapid transformation and impressive development that has ably empowered its citizenry, critical theory perspectives were, therefore, deemed useful in drawing lessons from South Korea's development success to inform Uganda's development process, especially its responsiveness to the needs of subaltern communities. Since most of the KOICA's supported projects were still in their execution stage at the time of study, focus was placed on their overall purpose and the participatory nature of their design and implementation.

The study was largely based on the review of secondary data to draw the broader reflection on South Korea's development success, while minimal primary sources 
were used to capture the reality of KOICA-supported development initiatives in Uganda. Secondary data was sourced, which included scholarly critiques of reports about South Korea's development experience, to provide evidence and analytical frameworks within which development initiatives undertaken by KOICA could be assessed and lessons drawn. Primary data was obtained through Key Informant Interviews (KIs) with KOICA officials in Kampala, Uganda so as to corroborate the evidence from secondary sources. The analysis of facts was informed by Korea's development programmes, projects and activities in Uganda under the coordination and supervision of KOICA, Uganda. Due to its qualitative nature, description and interpretation of facts was based on the stakeholders' responses about Korea's development experience in Uganda. Apart from the fact that most of the programmes and/or projects addressed were in their implementation phase, limited resources did not allow further interrogation on their actual performance. This is an area for further research, especially at the completion of the projects to further detail their effectiveness and efficiency, and their relevance and impact. The study was conducted between January and April 2014.

\section{Korea's development experience}

In discussing Korea's development experience and its lessons for developing countries, this article adopts the three-fold reference to development by Khan (2010). First, development is understood as a set of structural changes which make development possible and provide for its ultimate manifestation. Second, development is underpinned by explicit distributional elements that facilitate growth, and reduce poverty and inequality within the population. Thirdly, Khan adopts Sen's idea of 'development as freedom' and 'capability approach', where people's capabilities are developed to meet their human needs (Sen, 1999). The three aspects essentially testify to the communitarian nature of development as a public good and not merely as a private luxury. The aspects also provide key parameters and surest way to achieving equitable and sustainable development. Instructively, the three development parameters are also consistent with Korea's development experience and offer significant lessons for development impetus among developing countries, Uganda in particular (Khan, 2010).

Following the devastating effect of the Korean War (1950-1953), the United States General, Douglas MacArthur, who led the United Nations (UN) forces in 1950 during their defence of South Korea, noted that "Unless there is a miracle, it will take 100 years for South Korea to recover from the Korean war" (KOICA, 2011: 34). Indeed, the miracle occurred and within 50 years of signing the armistice that ended the hostilities on the peninsula, South Korea became a fully fledged member of the Organisation for Economic Cooperation and Development (OECD) in 1996. It also became a member of the Development Assistance Committee (DAC) in January 2010 , following an extensive accession process and a special session of the DAC on 25 November 2009. OECD/DAC represents the twenty-four most advanced countries in the world; therefore, DAC membership was a significant recognition of South Korea within the ranks of developed nations. South Korea's advanced development 
status is exemplified by its robust aid performance following its ascension to the OECD/DAC membership (KOICA, 2011).

According to Chang (2009), by the end of the Korean War in 1953 and close to the end of $1960 \mathrm{~s}$, Korea ranked $24^{\text {th }}$ among 125 poorest countries. With an annual per capita national income at 67 USD, South Korea was labelled by the United Nations (UN) as one of the world's Least Developed Countries (LDCs) alongside others such as Bangladesh, Ethiopia, Pakistan, Togo and Uganda. Impressively, South Korea progressed through a committed and miraculous social and economic development process supported by generous and substantial aid contribution from the wider international community to emerge from the status of an aid recipient country to a developed and donor country (Chang, 2009). Receiving aid totalling to 12 billion USD within six decades, South Korea miraculously transformed itself from the $24^{\text {th }}$ poorest country to an OECD/DAC member, officially withdrawing from the list of aid recipient countries in 1999. With the help of Official Development Assistance (ODA), South Korea leapt to the position of a donor country with per capita income approaching 20,000 USD by 2011 (KOICA, 2011). As a symbol of successful ODA in the international community, South Korea has since 1991 been working through KOICA to return the favour and share its impressive development experience with developing countries.

Instructive for this article, South Korea's own experience of utilising ODA continues to serve as a model for bridging the relationship between the ODA donors and developing countries. With the dramatic increase of its ODA size from 60 million USD in 1990 to 810 million USD in 2009, and the volume of multilateral ODA increasing from 48.9 million USD in 1990 to 230 million USD in 2009 (KOICA, 2010), South Korea is increasingly sharing its development experience and expertise. It has now risen to a position of reciprocating the generosity to give back to developing countries the same type of aid it had once received. In the same period, 1990 to 2009, Africa was recipient of 13\% of South Korea's bilateral ODA, making Africa South Korea's second largest regional recipient after Asia which received $63.6 \%$. South Korea's multilateral ODA consists of contributions to UN organisations, multilateral development banks including World Bank, other international organisations and non-governmental organisations (KOICA, 2010).

According to Leipziger (n.d), a specific combination of political and economic elements has been the key driver behind South Korea's development success. Both traditional and contemporary factors are cited as significant contributors to the country's growth. Traditional factors include prodigious savings, a focus on exports, investment in human and infrastructure capital, strong macroeconomic policies, and a capable government with a long-term development vision. Contemporary factors such as effective economic planning, strong business-government links, investment in research and development, adaptable economic policies and an emphasis on tertiary education are cited as increasingly being recognised as playing an equally important role. Moreover, other widely accepted and potentially replicable strategies include strong macroeconomic management, a strong national vision, well aligned economic policies, effective policy implementation, and monitoring for impact (Leipziger, n.d). 
The United Nations Development Programme (UNDP) Human Development Report (UNDP-HDR, 2013), which was launched in Seoul, further indicates that South Korea has some of the fastest rising rates of human development in recent years. The report attributes South Korea's fast development to the commendable role of the state in development and quality education, job creation, improved access to health, and the positive correlation among these factors. The report singles out South Korea's achievement in boosting quality education to help people fulfil their potential, with specific attention on the girl-child to boost women empowerment. Indeed, the report notes that while in the 1950s, a large proportion of school-age girls received no formal education; today, young South Korean women are among the best educated women in the world to the extent that more than half have completed college. In congruence with the major argument of this article and its theorisation of Khan's (2010) disposition on development, the report indicates that South Korea's experience in supplementing rapid economic growth with social policies that benefit society more broadly, especially the poor, offers lessons for the developing world (UNDP, 2013).

South Korea's growth and development are further attributed to its disciplined development policies aided by geo-strategic location and favourable demographic structure with low fertility rates and large working population (Chang, 2009). While Uganda boasts of a very high fertility rate with $75 \%$ of its population below the age of 30 years (State of Population Report, 2013), its youth population, when properly empowered and harnessed to the development needs, holds a great potential for rapid growth and transformation. To the disciplined development policies and geo-strategic location, Khan (2010) adds South Korea's fairly egalitarian society defined by ethnic homogeneity and limited threats of diversity especially the egalitarian land reform after the end of Japanese colonialism, and strong emphasis on agricultural development as also having contributed significantly to South Korea's fast growth and development. On the contrary, Uganda continues to grapple with an ethnically heterogeneous community and problematic land policies but could do well drawing lessons from South Korea's egalitarian policy orientation and land reforms.

It suffices to recall Chang's (2009) recognition of South Korea's disciplined development policies which ensured that international aid was well-managed and harnessed to buttress industrial growth that ensured international trade and inflow of foreign currencies, a critical point that Uganda and other developing countries should embrace. Some of the notable outcomes of South Korea's judicious development policies captured by Leipziger (n.d) include an unparalleled rise in income and the quality of human welfare. The country has nurtured world-class industries which are characterised by its dynamic manufacturing and technology sectors. Uganda ought to benchmark South Korea's income performance, reduction of inequality and improvement of human welfare as key focus points in structuring its industrialisation drive. It should be motivated by world-class technology brands such as Samsung, LG, and KIA, among others, which illustrate South Korea's robust technological and manufacturing advancement. 
Khan (2010) observes that by acknowledging South Korea's industrial development, effective structural innovation and changes, as well as creation of technological capabilities, South Korea's case stands out as a very apt illustration of creating technological capabilities throughout the entire growth and development trajectory in definite stages. Supplementing Khan's viewpoint, Lee (2008) points out that among various aspects of capabilities, much emphasis was placed on technological capabilities because without these, sustained growth is impossible. He further noted that in this era of open market competition, private companies cannot sustain growth if they rely on cheap products; they need to be able to move up the value-chain to higher-value added goods based on continued upgrading and improvement and technological innovation, a sound development drive that Uganda would emulate.

In addition, promotion of national innovation systems required South Korea to create specific institutions and technological learning over time. For South Korea's development to continue beyond the catching-up phase, it ultimately required crucial policy changes. The lessons on South Korea are summed up by Lee,

\begin{abstract}
While the ultimate goal and criterion of development is to raise the capabilities of local private companies, the process needs pilot agencies to guide and coordinate the whole process. Such needs exist because key resources are so scarce, and thus had better be mobilised for use in sectors or projects with greatest externalities. ...All the East Asian countries built specific state agencies that played a role in guiding the process of industrialisation. In [South] Korea the institutions established in the 1960s under the Park regime included the Economic Planning Board to set economic plans; the Ministry of Trade and Industry to support industrial policy and export; and the Ministry of Finance to finance economic plans (Lee, 2008: 4-5).
\end{abstract}

As noted by Khan (2010), both state and civil society have over time played important roles and significantly contributed to South Korea's development. According to him, at an earlier stage, the state necessarily plays a large and activist role. At a later stage, however, the creation of technological capability has to rely on a private-public partnership at both the precompetitive and the competitive phases of innovation (Khan, 2004). Drawing from Khan's exposition, Uganda's Public Private Partnership (PPP) Policy and Equal Opportunities Act provide key entry points to move forward Uganda's development trajectory.

Explicit in the above analysis is the fact that South Korea's development success espoused the three elements of development suggested by Khan (2010), namely development as a set of structural changes; explicit distributional elements that facilitate growth and reduce poverty and inequality; and people's capacity to meet their needs consistent with the 'capability approach'. This article argues that Uganda and other aid receiving countries can learn from South Korea's success story to inform their development trajectories and anchoring drive for sustainable economic 
development and social transformation in their unique socio-economic and political circumstances.

\section{A glimpse into South Korea's development initiatives in Uganda}

The study on Strategies for Utilising Evidence-Based Approach for Development effectiveness shows that South Korea's foreign aid was initiated and focused on the reconstruction of the war-ravaged economies of Europe and Japan since the Second World War (KOICA, 2013). Conversely, however, the focus of development assistance has been on poverty reduction and economic growth of the developing world. By early 1990s, the critical and often pessimistic perspective emerged with regard to the impact of foreign aid on developing countries. Consequently, the focus on the development agenda shifted from the amount of aid to aid effectiveness in achieving the development goals. World-wide, the call for policy coherence for development (PCD) increased; and the accountability and transparency of aid budget and implementation have been emphasised both inside and outside of the development community (Khan, 2004a). By and large, the concerns on the quality of aid have increased, and the evidence-based approach is increasingly gaining momentum towards improving the impact and evaluation of aid.

Since joining the Development Assistance Committee (DAC) in January 2010, South Korea has worked hard to strengthen its aid and contribution to global development efforts. During the consultative accession process to DAC membership, members expressed genuine admiration for Korea's success in transforming itself from an aid recipient (as recently as 1995) to an important aid donor in such a short space of time (KOICA, 2011). To ensure its effectiveness and sustainability, it is imperative that the South Korean government should be more cautious in managing the sudden increase in ODA. As noted by the study on Strategies for Utilising Evidence-Based Approach for Development effectiveness, South Korea should try to build on the ODA commitment on increasing volume and focus of aid and establishing stronger legislation and aid policies (KOICA, 2013).

As we noted earlier, KOICA is the official Grant Aid coordination and supervision agency of the government of South Korea in developing countries, including Uganda. KOICA has been operating in Uganda since December 2010. During an interview with a KOICA Official (April 11, 2014 in Kampala, Uganda), it was revealed that KOICA's main focus in Uganda (about $70 \%$ of total aid) is in agricultural support, focusing mainly on projects geared towards the provision of economic infrastructure and improvement of farmers' income and livelihoods. Given its preferential focus on rural or peri-urban communities, the focus of Korea's aid is consistent with the critical theory's focus on empowering the subalterns and Khan's (2010) postulation of development as underpinned by people's ability to meet their needs and explicit distributional elements that facilitate growth and reduce poverty and inequality within the population. Besides farmers' incomes and economic infrastructure, it was revealed in the same interview that KOICA also supports other sectors such as 
education and information and communication technology (ICT). All these development projects are explored at length below.

A presentation about the project, "Establishment of Vocational Training Institute in Uganda" revealed that South Korea's ODA consists of three types of aid: bilateral grants, bilateral loans and multilateral assistance. Bilateral grant comprises technical cooperation and various types of transfers (made in cash, goods, or services) with no obligation for repayment. KOICA is responsible for bilateral grant aid and technical cooperation programmes, where $90 \%$ of the total budget of South Korea's bilateral grant aid is allocated (Interview with KOICA Official, April 11, 2014, Kampala, Uganda).

In addition to the presentation, further interviews also revealed that KOICA finalised the Country Partnership Strategy (CPS) that contains details on how South Korea intends to assist Uganda to achieve its development objectives. This strategy is South Korean government's umbrella plan for providing official development assistance (ODA) to Uganda. Besides, the CPS was drawn up based on mutual understanding and respect for Uganda's national development plans, Vision 2040 and National Development Strategy (NDS). It focuses on improving the effectiveness of the assistance by linking South Korea's development experience and comparative advantages to Uganda's development demands. KOICA dispatches experts to provide technical assistance in the priority areas of cooperation and strengthen technical dialogue with the government of Uganda and other relevant stakeholders. This means that South Korea's development projects are consistent with and directly feed into Uganda's development objectives and priorities of transforming Uganda from a poor into a middle-income country as laid out in the National Development Plan, National Development Strategy and Vision 2040. It also embodies, in many ways, Khan's (2010) understanding of development as reflective of structural changes that make development possible, the ability to distribute resources so as to reduce poverty and inequality, and empowering people to meet their needs.

As we noted above, KOICA coordinates and manages different development projects in Uganda as was discovered through interviews with some officials who represent this organisation in Uganda and oversee the implementation of its supported projects. One of the development projects is Soroti Business Park, an agro-processing factory in Teso region, implemented for four years, between 2012 and 2016, costing 7.4 million dollars. The project specialises in the processing of citrus fruits and grains for making juice. It also offers technical and input support to farmers to improve productivity and household income. The South Korean government provided the funds for construction, machinery and equipment required for this project. More instructively, the South Korean government offered experts who would remain part of the project especially in monitoring and ensuring quality compliance. In another project, the South Korean government is supporting Uganda's National Information

\footnotetext{
${ }^{2}$ A presentation about the project, "Establishment of Vocational Training Institute in Uganda" by Korea International Cooperation Agency (KOICA), Kampala, Uganda
} 
Technology Authority in providing both soft and hardware support and provision of Information Communication Technology (ICT) equipment for government agencies, particularly the Ministries. The ICT project aims at ensuring efficient information generation, storage and dissemination for efficient decision making, monitoring of compliance and evaluation of policy and project outcomes to enhance compliance with ideals and standards in order to achieve value for money.

KOICA also established the National Farmers Leadership Centre in Kampiringisa, Mpigi district. The project focuses on improving crop varieties and poultry to enhance productivity. Established in 2011, the Centre was supported by KOICA until the end of 2014, costing 3.5 million dollars. The South Korean government provided all the funds for construction, provision of equipment and handling of curriculum development in collaboration with the Government of Uganda. Demonstration units for each agro-activity were established for the purpose of harnessing theory and practice. The project also seeks to secure market for agro-produce through formation of farmers groups, training of farmers, and research. Upon its successful completion, the project would be officially handed over to the Government of Uganda. This project is expected to enhance the capacity of the farmers, increase household income and improve people's livelihoods.

The other project is the establishment of a Vocational Training Institute in Ntinda, along the way to the Uganda Martyrs shrine. The project was implemented between 2011 and 2015, costing 4.5 million dollars. This is a long-term establishment aimed at developing the technical capacity especially of Uganda's youthful population, which would enhance their productive potential and enable them to earn an income. The vocational training focuses on market-driven skills such as motor vehicle repairing, electrical engineering, plumbing, welding and tailoring among others. It was edifying to note that South Korea government offered the funds for construction and procurement of all the equipment that was used. It also engaged in curriculum development and review for integration of Uganda and South Korea's experiences. For the first two years after the construction of the vocational training institute, South Korea offered expert instructors and volunteers to run the project. Thereafter, the training institute would be handed over to Uganda's Ministry of Education (Interview with KOICA Official, April 8, 2014, Kampala, Uganda).

Other projects include the Agro-processing and Marketing Strategy for Uganda (2013 and 2015), costing 2.5 million dollars. The other projects involve the preparation of a Master Plan for new towns within the Greater Kampala Metropolitan Area from 2014 to 2017, planned to cost 5.5 million dollars; and enhancing nutrition and increasing household income in Karamoja sub-region through vegetable cultivation and marketing strategy. The project on enhancing nutrition and increasing household income was implemented in conjunction with World Food Programme between 2012 and 2013 at a cost of 2 million dollars. This study was informed that KOICA provided funding and two experts all of which were essential for the success of the project. All these projects touch the core of Uganda's development interests and priorities; if they effectively and efficiently implemented effectively, they will 
respond, in a significant way, to the development needs of target communities and Uganda as a whole.

KOICA also runs fellowship programmes, basically offering tailored trainings. The Country-specific Fellowship Programmes for Uganda include the Policy Capacity Building on Increasing Farmers Income for 50 participants (2012-2014) and Capacity Building on Local Administration for 50 Local government officials (20122014). Besides the fellowship programmes, KOICA also works through partnership with Civil Society Organisations (CSOs). For instance, KOICA partnered with World Vision, Uganda to implement the Karamoja-Abim Food Security and Wash Project. The project was initially focusing on post-conflict resettlement and reconstruction in northern Uganda before it was scaled up to Karamoja region. The project extended and offered support to the Office of the Prime Minister (OPM) for the construction of houses in the reconstruction of Northern Uganda (Interview with KOICA Official, April 11, 2014, Kampala, Uganda).

It was further observed through an interview with a KOICA official in Kampala (April 8, 2014) that there are South Korean-based non-governmental organisations (NGOs) that have established operations in Uganda to facilitate development. These include Kkottongnae, which runs Home-based Orphans and Vulnerable Children (OVC) programmes through community outreach work under the Essential Care for HIV/AIDS affected OVCs (ECHO) project. The other NGOs include the Angel's Heaven, which offers education and empowerment for children and women in Kabarole District; Goodpartners Inc. Association, operating in post-war Northern Uganda and supporting the Gulu District Health Care service strengthening project; and the Sahmyook University, which runs a project to strengthen Health Centres in Luweero district. Sahmyook University project mainly focuses on strengthening health personnel and the management system of Health Centres (HCs) II, III and IV.

Interviews with KOICA officials in Kampala also revealed that Korea supported a Multilateral Cooperation under the South Korea Millennium Village Project in Ruhiira, Isingiro District (2014-2015). This project was implemented in partnership with the United Nations Development Program (UNDP). Its cardinal aim was to develop model villages crafted along the Millennium Development Goals (MDGs) indicators. The project supported various income generating activities (IGAs), and delved into sanitation and hygiene as well as provision of essential services, notably provision of education and health facilities for the community. In performing these functions, the project aims at strengthening families to ensure food security, improved household incomes and general standards of living. Anchored on core areas of human development and socio-economic transformation, this article notes the significant potential of KOICA development initiatives in contributing to and informing Uganda's development and transformation process. What is explicit in the design, focus and implementation of the project is the ideal intention of transforming society through improved capacity, income generation and ability to meet human needs with specific focus on marginalised communities. This approach does not only embody Khan's (2010) development framework adopted for this study, but is also consistent 
with the principles of critical theory research paradigm, which propagates emancipatory knowledge aimed at empowering the marginalised and subaltern communities.

\section{Conclusions and recommendations for Uganda}

Korea enjoys an impressive and phenomenal development experience (KOICA, 2011). South Korea's development experience drew heavily from global experience which informed benchmarks for anchoring development projects locally and through aid to developing countries. Informed by the development programmes, projects and activities supported by KOICA-Uganda, South Korea's growth and development initiatives in Uganda show, with particular credit, how South Korea's model has responded to national development objectives and priorities through communitybased, demand-driven and participatory models conducive for Uganda's equitable and sustainable growth and development. This development experience forms a viable model for participatory and sustainable development in Uganda and is consistent with Khan's (2010) development framework.

KOICA's future strategies are instructive for Uganda's development. These include the advancement of ODA implementation system through provision of localised assistance, decentralisation and devolution and compliance with and participation in the formation of International Rules on Aid; and enhancement of development effectiveness through establishment of a South Korean model for development cooperation, introduction and strengthening of programme based approach and management of results and strengthening evaluation. Others include the strengthening development partnership through expanding public-private partnership (PPP) and strengthening cooperation with international organisations; educating development specialists and developing ODA infrastructure; and supporting the development agenda of the G20 and Busan's High Level Forum four major agendas (HLF-4). The HLF-4 agendas are: development in vulnerable situations, effective institution formation, private sector and development, and effective promotion in development cooperation (KOICA, 2011). All these strategies, which replicate the development framework that guided the analysis, should be well studied and replicated to inform Uganda's development process.

In view of development programmes and projects in Uganda, it is clear that KOICA has clearly defined its own development objectives, priorities, main functions and strategic task ranges, its strategic role. This should be strengthened and harmonised with development objectives of Uganda and other partner countries. Reflecting the emancipatory framework of critical theory, Uganda should utilise development aid to meet the social transformation needs of its citizens. It is instructive to note that KOICA has adopted and prioritised the CPS implementation plan, provided for requisite flexibility for the CPS implementation plan to change from sectoral to thematic strategies and established simple and efficient CPS based on results. In addition, KOICA has clarified its role at all project levels, from project 
identification through policy dialogue and consultation with Uganda government. ${ }^{3}$ This is commendable because it would strengthen development programmes from the mid- to long-term basis. Caution, however, must be taken to guarantee effective and efficient implementation of the development aid, especially given the high corruption levels in Uganda today.

Uganda and other developing countries must garner confidence to consider that South Korea's development and transformation miracle is possible in their unique circumstances as long as a right political environment and development mindset is created to guide the process to fruition. This is particularly possible for Uganda given the improving literacy levels and entrepreneurship skills among Uganda's populace, towards which South Korea's development initiatives are oriented. Government must create an enabling environment to attract and support creativity and innovativeness among the population in the process of wealth creation. This should be done through skills-based training and development especially among the youth, establishment of collaboration with the manufacturing sector for industry-based internship apprenticeship, both locally and internationally, and robust support of cottage industry and small and medium productive enterprises that offer opportunities for creativity and innovation.

While South Korea was favoured by its enabling demographic structure of low fertility rates and a high working population, Uganda should not be bogged down by high fertility rates and burgeoning youthful population. According to the state of population report (December, 2013) Uganda is one of the countries with the highest population growth and has the youngest population worldwide, with $75 \%$ of its population below the age of 30 . Uganda must increasingly invest in human capital and social development and transformation strategies to ensure quality population that can meaningfully contribute towards development. A large youthful population should not be viewed necessarily as a negative demographic trend but must be robustly skilled and mobilised to contribute to the country's development. If well managed, creative energies and innovation of the youths can fundamentally contribute to national development and transformation.

Uganda's current development policy focuses on value creation and value addition through robust industrialisation and export-led growth enshrined in the National Development Plan (NDP) and consistent with South Korea's growth experience. This must be strengthened beyond mere political rhetoric to inform constructive and real development policies and strategies. The recent discovery of oil wells in Uganda and its current plan on oil extraction and management must generate the required revenues to feed into her industrial development plan. The jobs associated with oil extraction must be well positioned to offer the employees the financial capacity that will contribute to the overall national growth and development through improved household incomes.

\footnotetext{
${ }^{3}$ Interview with KOICA Official, April 9, 2014, Kampala Uganda
} 
Promises offered by the East African federation through the establishment of effective customs union and industrial development strategies should work to catalyse robust industrial growth, value addition, and market creation for industry products. Whereas agriculture still contributes about 75\% of Uganda's foreign exchange, investment in agriculture and agricultural infrastructure must be prioritised. South Korea's development aid that focuses on agriculture is of great value, and must be insulated from any possible leakages so as to meaningfully meet its intended development goals.

If Uganda is to attain its intended development goals, it must properly manage its share of international aid by learning from the South Korean experience. Fortunately, Uganda is often associated with having well-focused policies such as decentralisation, prosperity for all, public-private partnership and equal opportunity policies among others. Unfortunately, with marked low political will, ineffective governance system and weak policy monitoring infrastructure, these have more often than not remained on paper than in reality. Such well-intended and enabling policies must be well implemented and properly managed to meet the country's development needs. There is certainly need for a disciplined civil service and workforce supported by an enabling political environment and sufficient good political will and dispensation from those at the helm of government to enable effective and efficient implementation of these policies.

Furthermore, Uganda has presided over stable micro and macro-economic policies that have consistently kept Uganda's growth and development rate averaging between $6 \%$ and $8 \%$ over the last three decades. Similarly, Uganda has enjoyed fairly stable monetary and fiscal policies that have over the years tamed the inflation to remain within a single digit figure, except during moments of famine precipitated by low agricultural productivity and periods of parliamentary and presidential elections because of a monetised and highly commercialised electoral process. Picking lessons from South Korea's development success, Uganda must strongly desist from commercialisation of politics, strengthen monetary and fiscal discipline, and ensure effective and efficient implementation of development policies and strategies as well as programmes and projects.

On its part, KOICA should remain steadfast in its commitment to create an appropriate environment to enable effective management systems and strategies for long-term development endeavours. As such, the government of Uganda with support from KOICA and other aid agencies should strengthen specialised aid management within project implementation systems and establish mechanisms for improving awareness on design, implementation, monitoring and evaluation of development initiatives. The government and the implementing partners should as much as possible involve the aid-beneficiary communities in the entire project cycle to ensure relevancy, responsiveness and ownership. Strengthening the sense of public ownership of these development projects could also go a long way in mitigating resource leakages and ensuring maximum benefits for intended beneficiaries. As 
noted by Leipziger (n.d), the world will likely see that a quick and coordinated policy response, which has long been a hallmark of South Korean policymakers, work yet another time.

KOICA should also ensure and strengthen mutual cooperation and management methods within Uganda and other partner countries. Through mutual collaborative strategies and partnerships, KOICA would be able to maximise effective management and minimise the administrative burden. All these recommendations will be possible if KOICA addresses human resource needs, both in Korea and within Uganda and other donor or aid recipient countries. Firm and strong effective and efficiency controls must be established to promote transparency and accountability, thus minimising flows through corruption.

Finally, KOICA must clarify functions, roles and expertise of all the stakeholders to ensure value for money and maximum outputs. Plans for human resource planning, management and expertise strengthening among the implemented projects must be established and entrenched to offer impartial services for the beneficiary community. More importantly, strict measures for accountability must be established with partner countries to avert looming misappropriation of resources and guarantee efficient results and value for money.

As noted by Leipziger (n.d), there is much that developing countries can learn from the South Korean development experience. The first is that economic fundamentals matter; not just to satisfy donors, but to actually position the economy to be better managed for the sake of progress. Second, the distribution of income and social programmes are important; once again, not to satisfy donors, but to maintain broad-based public support for reforms. Third, the private sector should work with government through effective and responsive public private partnership development initiatives, especially if the actions of government and business can be aligned. Fourth, financing social infrastructure and building the social contract between citizens and governments should be a central element of public policy. It is critical that governments solicit taxes from their citizens and that citizens demand quality government services in return. Finally, government-led economic planning has been the template for all East Asian success stories and has the potential to prove similar results in other countries. Uganda should study and draw lessons from South Korea's government-led economic planning process to strengthen its economic planning capacity and improve delivery of outputs.

This article concludes with the words of Park Dae-won, KOICA's President, in his preface statement in the 20 Years of KOICA,

KOICA has actively responded to these external and internal demands. In the coming 10 or 20 years, KOICA will make great strides as an institution of international development cooperation. Now it is time to pay attention to the qualitative growth of our development cooperation aid. We should focus all of our capacity in designing and implementing development cooperation projects that encompass our own development philosophy and sensibilities. As an architect of love, happiness, and 
dreams, dedicating our sincere hearts to the developing countries will make a better world for all (KOICA, 2011).

Sincere adherence to such powerful sentiments would illuminate benchmarks for qualitative, efficient and sustainable development aid, and provide critical lessons for other aid givers if their generosity is to achieve economic and social transformation among developing countries.

\section{References}

Chang, D., 2009. Capitalist development in Korea: Labour, capital and the myth of the developmental state. Advances in Korean Studies: Routledge, New York

Khan, H.A., 2010. Development strategies: Lessons from the experiences of South Korea, Malaysia, Thailand and Vietnam. Working Paper No. 2010/10, United Nations University, UNU-WIDER

Khan, H. A., 2004. Innovation and growth in East Asia: The future of miracles. Houndsmills and New York: Macmillan/Palgrave

Korea International Cooperation Agency, 2014. Happiness for all, with global KOICA. [Online] Available From: http://www.koica.go.kr/english/koica/mission/index.html [Accessed 11 April 2014]

Korea International Cooperation Agency, 2011. 20 years of KOICA, 1991-2010. KOICA, November 2011

Korea International Cooperation Agency, 2013. Studies of policy-making and project management systems in other agencies. KOICA

Korea International Cooperation Agency, 2013. Studies on aid for trade in developing countries. KOICA

Korea International Cooperation Agency, 2013. Strategies for utilising evidencebased approach for development effectiveness. KOICA

Korea International Cooperation Agency, 2013. Study on multilateral cooperation: Enhancement of a comparison between multi-bi and bilateral projects. KOICA

Korea International Cooperation Agency, 2012. Study on policies and projects for humanitarian assistance. KOICA

Korea International Cooperation Agency, 2012. Study on e-government models. KOICA

Korea International Cooperation Agency, 2012. Study on the enhancement of technical cooperation in Korea. KOICA

Lee, K., 2008. Can Korea be a Role Model for Development? A "Capability-based View" on Korea', Paper presented at the WIDER conference on country role models for development success, 13-14 June. Helsinki: UNU-WIDER

Leipziger, D.M., n.d. Past \& Current Lessons from Korea's Experience. Remarks prepared for the Korea-World Bank conference on post-crisis growth and development. George Washington University School of Business

Sen, A., 1999. Development as freedom. Oxford: Oxford University Press and New York: Alfred A. Knopf, Inc. 
Population Secretariat \& United Nations Population Fund, 2013. The state of Uganda population report, Uganda at 50 years, population and service delivery: Challenges, opportunities and prospects. The Republic of Uganda

United Nations, 2013. The rise of the south: Human progress in a diverse world. The Human Development Report, UNDP

\section{Author Biography}

Denis Musinguzi $(\mathbf{P h D})$ is a Development and Policy Lecturer/Researcher in the School of Arts and Social Sciences, Uganda Martyrs University. He specialises in the areas of development policy and strategies, governance and social transformation. $\mathrm{He}$ currently heads the Department of Governance and Peace Studies under the School of Arts and Social Sciences at Uganda Martyrs University. 